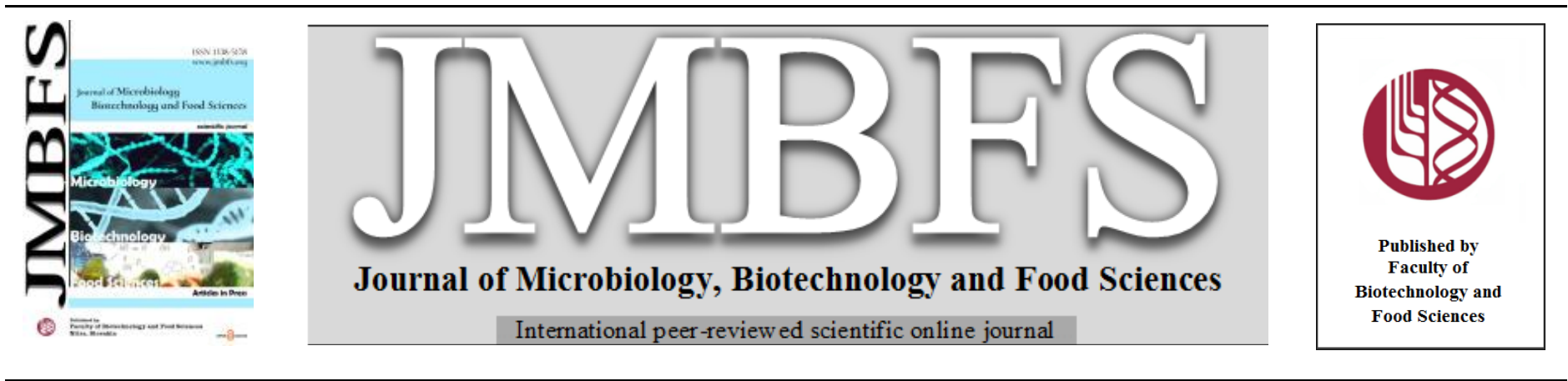

\title{
INTERNAL FATS OF ROSS 308 BROILER CHICKENS AFTER APPLICATION OF GRAPE, FLAX AND PUMPKIN POMACE INTO THEIR DIET
}

\author{
Matej Čech*l, Peter Haščík ${ }^{l}$, Juraj Čuboñ ${ }^{l}$, Peter Herc ${ }^{l}$, Lukáš Jurčaga ${ }^{l}$, Marek Bobkol , Miroslava Kačániováa \\ Address(es): Ing. Matej Čech, \\ ${ }^{1}$ Slovak University of Agriculture in Nitra, Faculty of Biotechnology and Food Science, Institute of Food Science, Tr. A. Hlinku 2, 94976 Nitra, Slovakia \\ ${ }^{2}$ Slovak University of Agriculture in Nitra, Faculty of Horticulture and Landscape Engineering, Institute of Horticulture, Tr. A. Hlinku 2, 94976 Nitra, Slovakia
}

*Corresponding author: matej.mcech@gmail.com

https://doi.org/10.55251/jmbfs.5347

ARTICLE INFO

Received 30. 9. 2021

Revised 14. 2. 2022

Accepted 21. 2. 2022

Published 1. 8. 2022

Regular article

open 2 access

\begin{abstract}
Poultry fat is interesting in terms of fatty acid composition, especially due to the higher content of unsaturated fatty acids compared to mammals. However, internal fats are considered as one of the wastes from poultry processing. In previous experiments, we observed the effect of grape, flax and pumpkin pomace on the meat performance and chemical composition of broiler chicken muscle. Therefore, the aim of this work was to examine the effect of these pomaces on the formation of internal fats in Ross 308 broiler chickens. The control group (C) was fed with a feed mixture (FM) without antibiotics and growth stimulators. In the experimental diets, wheat in FM was replaced by 1, 2 and 3\% red grape pomace, variety Alibernet (groups E1, E2 and E3), 2 and 4\% flax pomace (groups E4 and E5) and 2 and $4 \%$ pumpkin pomace (groups E6 and E7). The chickens were fed and watered ad libitum for 42 days. Amounts of internal fats are presented as \% from carcass weight $(\mathrm{CW})$. Of the internal fats in females, only heart fat was significantly affected $(\mathrm{P} \leq 0.05)$ (least in E5 and $\mathrm{E} 7-0.20 \%)$. In males, on the other hand, we found significant differences $(\mathrm{P} \leq 0.001)$ in other fats: abdominal fat was highest in $\mathrm{E} 2$ and E3 (0.94 and $0.91 \%$, respectively), gizzard fat was highest in E2 (0.59\%) and internal fats together in E2 and E3 (1.67 and $1.48 \%$, respectively). The results show that negatively higher internal fat content of the chicken carcass was caused mainly by the addition of 2 and 3\% RGP in the diet of Ross 308 chickens.
\end{abstract}

Keywords: broiler chicken, internal fats, grape, flax, pumpkin, pomace

\section{INTRODUCTION}

Despite several recent challenges throughout the meat chain, world meat production is expected to increase in 2021. Stagnation in the pig meat and sheep meat trade is offset by higher trade in poultry and beef. Numerical assumptions assume an increase in global meat production by 2.2 percent to 346 million tons in 2021. This is mainly due to the recovery of production in the EU, USA, People Republic of China, Vietnam, and Brazil. Trade contractions in Australia, the Philippines and Argentina also contributed to this. The vaccination increase in the EU and the United States and thus the revival of food sales and the entire gastronomy sector, as well as the improvement of hygiene measures and the provision of various government assistance to the livestock sector to mitigate the negative trade effects related to COVID-19, also play a significant role in this recovery (FAO, 2021). Concentrating on poultry meat, its global output is predicted to grow by $1.3 \%$ to 135 million tons. This is driven by globally expected slight expansions, but mainly by gains in China, Brazil, and the EU (FAO, 2021). New breeds of broiler chickens with great meat performance are selected for quick, effective and low-cost rearing thanks to optimized feed conversion ratio. However high growth rate and final body weight triggers some of the meat quality problems (especially chickens' woody breast and white stripping) (Chen et al., 2019; Petracci et al., 2019).

Mentioned increase in growth rate achieved by selecting the best broiler chickens breeds through genetic selection in broiler chickens has been also associated with increased internal fats deposition. These intermuscular fats are one of the main wastes of the chicken processing industry. On the other side, intramuscular fats are necessary for delighted taste, tenderness and mainly juiciness of meat (Tủmová and Teimouri, 2010).

The re-use of chicken processing industry by-products, which still have interesting nutritional value, such as bones, intestines, internal fats, legs, heads, blood and feathers, would generally contribute to the sustainability and increase the value of the food industry. In general, these products are either disposed of in rendering plants or sold at low purchase prices for processing into petfood (Boushy and van der Poel, 1994; Barbut, 2015; Vikman et al., 2017) and, more recently, to produce biodiesel (Abid and Touzani, 2017). There are no known or very few reports that indicate the direct use of these by-products in human nutrition. For example, the internal fats of broiler chickens, especially internal fats of chickens, which represent about $2-2.5 \%$ of the carcass, could be used in the production of soft meat products, such as chicken sausages, which would be therefore enriched with unsaturated fatty acids (Gioielli, Ming and Sotero Solis, 2002). However, small chicken meat producers generally dispose of these internal fats together with intestines, feathers and blood, which creates a problem for the environment (PeñaSaldarriaga, Fernández-López and Pérez-Alvarez, 2020).

However, chicken fats content of polyunsaturated fatty acids is associated with poor oxidative stability (Moser, 2010). The predominant fatty acids in chicken fats are described as oleic, palmitic, and linoleic, compared to saturated fatty acids of fats (for example pig fat) that are generally used in meat products. Valorization of chicken by-products using internal fats as fat source in soft chicken meat products could be an alternative contributing to the poultry sector sustainability (PeñaSaldarriaga, Fernández-López and Pérez-Alvarez, 2020).

Feed antibiotics (also known as antibiotics grow promoters - AGP) have been used as a major barrier against the spread of bacterial infections in broiler chickens. Their effect consisted in direct protection with antibacterial agents, respectively by adjusting the intestinal microflora, reducing the incidence of intestinal infections in livestock and thus their overall better physical health and increased production (Costa et al., 2017; Ritter et al., 2019). However, the widespread use of feed antibiotics around the world has led to the development of resistant strains of bacteria against antibiotics for the treatment of human diseases. Therefore, in 2006 , their use in the EU was banned by a decision of the European Commission (Haščík et al., 2018). In 2011, research found that approximately $48 \%$ of producers in the world keep broiler chickens without the use of antibiotics, using them only when necessary (MacDonald, 2014). More recent findings estimate that more than $50 \%$ of industrially bred broiler chickens are reared without the use of feed antibiotics (National Chicken Council, 2019). This type of breeding is called NAE (No Antibiotics Ever). Broiler chickens kept with this system are prohibited from administering any antibacterial agents in feed mixture, water or injections throughout whole life (Newman, 2018). The mortality of broiler chickens in NAE production has increased by $25-50 \%$ compared to conventional production (Salois, 2017) and is on average around $4.2 \%$, while in conventional production using antibiotics approximately $2.9 \%$ (Ritter et. al, 2019).

Feed costs are main part of the overall animal production cost and according to Donohue and Cunningham (2009) it could be up to $80 \%$ of production costs Overall cost of feed can be affected by demand from other markets than animal production, such as biofuel industry and its demands for corn or wheat, which are main component in feed mixtures (Donohue and Cunningham, 2009; Masey O'Neill et al., 2012). Therefore it is necessary to find new products such as agricultural by-products with relatively high nutritional value. 
Wine production makes a significant contribution of the agricultural and beverage industry. According to International Organization of Vine and Wine (2021), more than 270 million hectoliters of wine were produced worldwide in 2016. The wine industry generates a huge amount of waste, which consists of stems, GP, sewage waters and yeast sludge. The treatment or disposal of these can have a toxic impact on the environment (Ilyas et al., 2021). According to Mendes et al. (2014) and Garcia-Lomillo and Gonzalez (2017) for every 6 liters of wine, about $1 \mathrm{~kg}$ of GP is produced. Traditionally, GP is incorporated into the soil or as feed for livestock. GP can also be used to produce value-added products thanks to various organic acids (tartaric, malic and citric acid), alcohol, fiber and grape seed oil with a positive fatty acid composition (Maier et al., 2007). In addition, GP is a source of various polyphenols, including flavonoids, anthocyanins, proanthocyanidins, and phenolic acids (Fontana et al., 2013; Beres et al., 2017; Garcia-Lomillo and Gonzalez, 2017; Del Pino-García et al., 2017). The protein content of GP is about $14 \%$, the lipid content $4-11 \%$ thanks to the presence of oil - rich seeds. They generally contain a lot of fiber, ranging from 26 to $70 \%$, exceptionally with a lignin level of about $18-55 \%$. The sugar content can vary from $4-9 \%$ in RGP up to 28 $-31 \%$ in pomace from special types of white wine (Heuze and Tran, 2020). The nutrient and bioactive compounds present in the GP make them a suitable candidate for use in animal nutrition (Aditya et al., 2018).

The fatty acid composition of monogastric animals is directly affected by the fatty acid composition of the feed. Flaxseeds are characterized by high concentrations of $\alpha$-linolenic acid (ALA) among oilseeds. They contain $35-45 \%$ fat, of which ALA represents $45-52 \%$. Therefore, the inclusion of flax seeds as a rich source of omega-3 fatty acids in the nutrition of monogastric animals makes it possible to adjust the fatty acid profile in poultry meat, in particular the omega-6:3 ratio (Newkirk, 2015). On the other side, due to their fatty acids' composition, such diets are exposed to a higher lipid oxidation and may require the use antioxidants (Turcu et al., 2018)

Pumpkin seeds (Cucurbita pepo) can also be one of the alternatives as a rich source of protein in the poultry industry (Wafar et al., 2017). Martinez et al. (2010) reported that pumpkin seeds contain $30.6 \%$ crude protein, $4.5 \%$ ash, $34.5 \%$ fat and $16.24 \%$ crude fiber; protein content in the cake after pressing the pumpkin seeds can even be up to around $54 \%$

Production of wine, flaxseed and pumpkin oil is associated with production of voluminous by-products also known as oilcakes or pomace. These, as mentioned above, still have an interesting nutritional composition and therefore also in view of our previous researches (Haščík et al., 2020; Čech et al., 2021; Jurčaga et al., 2021) the aim of this study is to explore potential negative effect of red grape, flax and pumpkin pomace on the amount of internal fats in broiler chickens Ross 308.

\section{MATERIAL AND METHODS}

\section{Animals and experimental design}

The experiment was realized in the Slovak University of Agriculture (SUA) in Nitra (Test poultry station Kolíňany) according to methodology of Haščík et al. (2020).

Diets were prepared following the recommended reference levels (Bulletin of MARD SR, 2005) to meet nutritional needs of broiler chickens. Broilers were subjected to a two-phase feeding program, starter HYD-01 $(1-21 \mathrm{~d})$ and grower HYD-02 (22 - 42 d) diets. Their composition are presented in Table 1. The starter and grower feed mixtures were produced without any antibiotics and coccidiostatics and were prepared by Biofeed, Inc. (Kolárovo, Slovak Republic). The experimental groups were set up as follows: the control group (C) fed with complete FM; the experimental group E1 fed with basal diet plus RGP $1 \mathrm{~kg} .100$ $\mathrm{kg}^{-1}$ of FM; experimental group E2 fed with a complete FM plus RGP $2 \mathrm{~kg} .100 \mathrm{~kg}$ ${ }^{1}$ of FM, experimental group E3 fed with a complete FM plus RGP $3 \mathrm{~kg} .100 \mathrm{~kg}^{-1}$ of FM, experimental group E4 fed with a complete FM plus flax pomace $2 \mathrm{~kg}$. 100 $\mathrm{kg}^{-1}$ of FM, experimental group E5 fed with a complete FM plus flax pomace 4 $\mathrm{kg} .100 \mathrm{~kg}^{-1}$ of FM, experimental group E6 fed with a complete FM plus pumpkin pomace $2 \mathrm{~kg} .100 \mathrm{~kg}^{-1}$ of FM and experimental group E7 fed with a complete FM plus pumpkin pomace $4 \mathrm{~kg} .100 \mathrm{~kg}^{-1}$ of $\mathrm{FM}$.

Table 1 Composition of feed mixtures

\begin{tabular}{|c|c|c|}
\hline Ingredients (\%) & $\begin{array}{c}\text { Starter (HYD-01) } \\
\left(1^{\text {st }}-21^{\text {st }} \text { day of age }\right)\end{array}$ & $\begin{array}{c}\text { Grower (HYD-02) } \\
\left(22^{\text {nd }}-42^{\text {nd }} \text { day of age }\right)\end{array}$ \\
\hline Wheat & 34.50 & 30.00 \\
\hline Maize & 28.00 & 39.00 \\
\hline Soybean meal $(48 \% \mathrm{~N})$ & 31.00 & 26.00 \\
\hline Fodder lime & 0.65 & 0.60 \\
\hline Calcium formate & 0.80 & 0.80 \\
\hline Monocalcium phosphate & 0.90 & 0.55 \\
\hline Fodder salt & 0.20 & 0.20 \\
\hline Sodium bicarbonate & 0.20 & 0.20 \\
\hline Lysine & 0.10 & 0.05 \\
\hline Methionine & 0.15 & 0.15 \\
\hline Soybean oil & 3.00 & 1.95 \\
\hline Premix Euromix BR 0.5\%* & 0.50 & 0.50 \\
\hline \multicolumn{3}{|l|}{ Nutrient content $\left(\mathrm{g} \cdot \mathrm{kg}^{-1}\right)$} \\
\hline Linoleic acid & 27.82 & 24.04 \\
\hline Fibre & 28.71 & 27.84 \\
\hline Crude protein & 209.68 & 189.60 \\
\hline Ash & 45.45 & 39.59 \\
\hline Ca & 8.12 & 7.27 \\
\hline $\mathbf{P}$ & 6.04 & 5.13 \\
\hline $\mathbf{N a}$ & 1.61 & 1.58 \\
\hline $\mathrm{ME}_{\mathrm{N}}\left(\mathrm{MJ} \mathrm{kg}^{-1}\right)$ & 11.92 & 11.92 \\
\hline
\end{tabular}

\section{Slaughter and measurements}

After fattening period (42 days), 10 males and 10 males of hybrid combination Ross 308 were selected from each experimental group based on average weight. Broiler chickens were weighed for determining the live weight and then killed by conventional neck cut in the experimental slaughterhouse of the Institute of Food Science (SUA, Nitra). After bleeding out, the feathers were removed from the broiler chickens and they were dissected. The carcass weight was determined and thereafter the abdominal fat, gizzard fat, heart fat and these fats together were weighted after the dissection. By calculating from the carcass weight, we found out their percentage.

\section{Statistical analysis}

The obtained results were subjected to statistical analysis by XLSTAT program (Addinsoft, Paris, France, 2017), using analysis of variance (ANOVA) to obtain baseline values, which are presented as mean \pm standard deviation. To determine the statistical evidence between the individual experimental groups, we used the Duncan test and the differences were considered significant at $\mathrm{P} \leq 0.05$.

\section{RESULTS AND DISCUSSION}

The results of an experiment aimed at determining the percentage of internal fat from carcass weight after the addition of Alibernet variety RGP, flax and pumpkin pomace are given in Tables 2 and 3, respectively: carcass weight, \% of abdominal fat, $\%$ of gizzard fat, $\%$ of heart fat and $\%$ of listed fats together. 
Table 3 Carcass weight (g) and internal fats (\% of CW) of female Ross 308 broiler chickens

\begin{tabular}{lccccc} 
Group & $\mathbf{C W}$ & $\mathbf{A F}$ & $\mathbf{G F}$ & HF & FT \\
C & $1381.80 \pm 48.44^{\mathrm{b}}$ & $0.58 \pm 0.10$ & $0.42 \pm 0.12$ & $0.15 \pm 0.05^{\mathrm{ab}}$ & $1.16 \pm 0.19$ \\
E1 & $1360.60 \pm 59.71^{\mathrm{b}}$ & $0.60 \pm 0.12$ & $0.40 \pm 0.16$ & $0.14 \pm 0.03^{\mathrm{b}}$ & $1.13 \pm 0.16$ \\
$\mathbf{E 2}$ & $1402.80 \pm 57.91^{\mathrm{b}}$ & $0.64 \pm 0.10$ & $0.41 \pm 0.13$ & $0.14 \pm 0.04^{\mathrm{b}}$ & $1.18 \pm 0.18$ \\
E3 & $1478.20 \pm 35.49^{\mathrm{a}}$ & $0.73 \pm 0.10$ & $0.46 \pm 0.08$ & $0.10 \pm 0.02^{\mathrm{b}}$ & $1.28 \pm 0.14$ \\
E4 & $1222.60 \pm 63.87^{\mathrm{c}}$ & $0.55 \pm 0.19$ & $0.39 \pm 0.11$ & $0.12 \pm 0.05^{\mathrm{b}}$ & $1.06 \pm 0.25$ \\
E5 & $1511.80 \pm 33.07^{\mathrm{a}}$ & $0.63 \pm 0.07$ & $0.53 \pm 0.13$ & $0.20 \pm 0.05^{\mathrm{a}}$ & $1.37 \pm 0.18$ \\
E6 & $1277.60 \pm 57.86^{\mathrm{c}}$ & $0.50 \pm 0.13$ & $0.46 \pm 0.13$ & $0.15 \pm 0.03^{\mathrm{ab}}$ & $1.11 \pm 0.23$ \\
E7 & $1404.00 \pm 26.26^{\mathrm{b}}$ & $0.52 \pm 0.11$ & $0.32 \pm 0.07$ & $0.20 \pm 0.03^{\mathrm{a}}$ & $1.03 \pm 0.10$ \\
\hline p-value & $<0.001$ & 0.101 & 0.231 & 0.003 & 0.114 \\
\hline
\end{tabular}

Legend: C - Control group; E1-E7 - Experimental groups 1-7 CW - carcass weight; \% AF - percentual amount of abdominal fat; \% GF - percentual amount of gizzard fat; \% HF - percentual amount of heart fat; \% FT - percentual amount of internal fats in total; a,b,c - different superscripts mean significant differences between experimental groups at significance level $\mathrm{P} \leq 0.05$ or $\mathrm{P} \leq 0.001$

Table 4 Carcass weight (g) and internal fats (\% of CW) of male Ross 308 broiler chickens

\begin{tabular}{|c|c|c|c|c|c|}
\hline Group & $\mathrm{CW}$ & $\mathbf{A F}$ & GF & HF & FT \\
\hline $\mathbf{C}$ & $1520.20 \pm 59.04^{\mathrm{ab}}$ & $0.66 \pm 0.14^{\text {bc }}$ & $0.50 \pm 0.15^{\mathrm{ab}}$ & $0.10 \pm 0.02$ & $1.26 \pm 0.22^{\mathrm{b}}$ \\
\hline E1 & $1508.20 \pm 79.94^{\mathrm{ab}}$ & $0.73 \pm 0.12^{\mathrm{b}}$ & $0.37 \pm 0.06^{\mathrm{cd}}$ & $0.12 \pm 0.03$ & $1.22 \pm 0.13^{\mathrm{b}}$ \\
\hline E2 & $1519.60 \pm 55.59^{\mathrm{ab}}$ & $0.94 \pm 0.13^{\mathrm{a}}$ & $0.59 \pm 0.11^{\mathrm{a}}$ & $0.15 \pm 0.04$ & $1.67 \pm 0.23^{\mathrm{a}}$ \\
\hline E3 & $1562.60 \pm 35.05^{\mathrm{a}}$ & $0.91 \pm 0.12^{\mathrm{a}}$ & $0.43 \pm 0.08^{\mathrm{bc}}$ & $0.15 \pm 0.02$ & $1.48 \pm 0.13^{\mathrm{a}}$ \\
\hline E4 & $1490.00 \pm 67.39^{\mathrm{ab}}$ & $0.56 \pm 0.07^{\mathrm{cd}}$ & $0.38 \pm 0.06^{\mathrm{bcd}}$ & $0.14 \pm 0.05$ & $1.08 \pm 0.14^{\mathrm{bc}}$ \\
\hline E5 & $1361.40 \pm 80.45^{\mathrm{c}}$ & $0.62 \pm 0.08^{\text {bcd }}$ & $0.44 \pm 0.09^{\mathrm{bc}}$ & $0.13 \pm 0.03$ & $1.18 \pm 0.15^{\mathrm{b}}$ \\
\hline E6 & $1432.60 \pm 39.99^{\mathrm{bc}}$ & $0.40 \pm 0.10^{\mathrm{d}}$ & $0.30 \pm 0.04^{\mathrm{de}}$ & $0.12 \pm 0.02$ & $0.90 \pm 0.13^{\mathrm{c}}$ \\
\hline E7 & $1499.20 \pm 49.33^{\mathrm{ab}}$ & $0.62 \pm 0.07^{\text {bcd }}$ & $0.22 \pm 0.04^{\mathrm{e}}$ & $0.10 \pm 0.03$ & $0.94 \pm 0.10^{\mathrm{c}}$ \\
\hline p-value & $<0.001$ & $<0.001$ & $<0.001$ & 0.112 & $<0.001$ \\
\hline
\end{tabular}

Legend: C - Control group; E1-E7 - Experimental groups 1-7 CW - carcass weight; \% AF - percentual amount of abdominal fat; \% GF - percentual amount of gizzard fat; \% HF - percentual amount of heart fat; \% FT - percentual amount of internal fats in total; a,b,c,d,e - different superscripts mean significant differences between experimental groups at significance level $\mathrm{P} \leq 0.05$ or $\mathrm{P} \leq 0.001$

In females we found the highest carcass weight after application of $3 \%$ RGP (group E3) and 4\% linseed pomace to the FM (group E5), namely $1478.20 \mathrm{~g}$ and 1511.80 g, respectively. These differences were significant $(\mathrm{P}<0.001)$ compared to the control and all the other experimental groups. On the contrary, the significantly lowest $(\mathrm{P} \leq 0.001)$ carcass weight was observed after application of $2 \%$ pumpkin pomace (group E6), namely $1277.60 \mathrm{~g}$.

In males, the highest carcass weight $(\mathrm{P} \leq 0.001)$ was also observed after the application of RGP in an amount of 3\% (group E3) in comparison with experimental groups E5 and E6. The significantly lowest carcass weight $(\mathrm{P} \leq 0.001)$ in males was in the experimental group E5 after the application of $4 \%$ of flax pomace, in comparison with all experimental groups except E6.

In females, we observed significant differences only in $\%$ of heart fat, which namely after the addition of $4 \%$ flax pomace (E5) as well as after $4 \%$ pumpkin pomace (E7), both $0.20 \%$. These differences were significant $(\mathrm{P} \leq 0.05)$ compared to experimental groups E1, E2, E3 and E4. We did not observe any significant differences in other internal fats and their amounts ranged from $0.50 \%$ (E6) to 0.73 (E3) in abdominal fat, from $0.32 \%$ (E7) to $0.53 \%$ (E5) in gastric fat and for fats together from $1.03 \%$ (E7) to $1.37 \%$ (E5).

In males, on the other hand, we did not observe significant differences only in the $\%$ amount of the heart fat, where it was in similar values in all experimental groups, on average $0.13 \%$. On the other hand, we observed significant differences in al other parameters. Abdominal fat was the highest $(\mathrm{P} \leq 0.001)$ in males after application of RGP in the amount of 2 and 3\% (group E2 - $0.94 \%$ and E3 - $0.91 \%$ ) compared to all other experimental groups and the least in group E6 after application $2 \%$ pumpkin pomace $-0.40 \%$. Similarly, the significantly lowes $(\mathrm{P} \leq 0.001)$ proportion of gizzard fat was also in this experimental group, namely $0.22 \%$ and the highest in experimental group E2 $-0.59 \%$. The above results were also reflected in the $\%$ of total internal fats from the carcass in males and thus the significantly highest $(\mathrm{P} \leq 0.001)$ amounts were observed after the application of RGP in the amount of 2 and $3 \%$ (group E2 - $1.67 \%$ and E3 - 1, 48\%) compared to the other groups and the significantly lowest amount of internal fats after application of 2 and $4 \%$ pumpkin pomace (group E6 - 0.90 and E7 - 0.94\%).

In our previous researches, we found out, that addition of RGP into Ross 308 broiler chicken diet significantly increased live body weight (Haščík et al., 2020), also increased amount of desirable intramuscular fat as taste promoter (Čech et al., 2021) without significant increase of malondialdehyde what indicates protective effect of antioxidant compounds present in RGP (Jurčaga et al., 2021).

Our results are comparable to Brenes et al. (2008), who observed the highest proportion of abdominal fat after the application of grape marc in the amount of $1.5 \%-0.90 \%$ compared to the control group $-0.70 \%$. Compared to the contro group, they observed slightly higher amounts of abdominal fat even after the application of 3 and $6 \%$ grape pomace. The results of the experiment of Hašćík Kačániová and Vavrišinová (2014) confirmed a higher proportion of abdominal fat from carcass weight in the experimental groups fed with probiotic preparation IMB $52(2.08-2.29 \%)$ applied in feed mixtures compared to the control group $(1.90 \%)$. Compared to us, slightly higher abdominal fat results were described by
Haščík et al. (2016) after addition of propolis extract $-1.31 \%$ and probiotics preparation $-1.48 \%$ proportion compared to control group $-1.36 \%$. Significantly higher amounts of abdominal fat are described by Nunes et al. (2012) after application of cysteamine to the feed mixture of Cobb 500 broiler chickens $(2.47 \%)$ compared to the control group (2.28\%). A higher amount of abdominal fat was also observed by Taufik and Maruddin (2019) after the application of garlic solution to the nutrition of broiler chickens Lohmann MB 202, when its amount ranged from $2.35 \%$ in the control group to $2.51 \%$ in the group with the highest amount of added garlic solution. Similarly high amount of abdominal fat was described by Griffiths, Leeson and Summers (1978) in study on abdominal fat with four commercial strains of male broiler chicken, where its amount ranged from 2.44 to $2.76 \%$. Methionine deficiency in broiler chickens diet in study of Kiraz and Sengül (2011) led to final abdominal fat content on level 1.62 and $1.73 \%$ in experimental groups. Insoluble granite-grit supplementation in study of Erener et al. (2016) to broilers diet led to slightly lower amount of abdominal fat $(2,07 \%)$ compared to control group $(2,10 \%)$. With dietary animal fat increased $(4,7$ and $10 \%$, respectively), amount of abdominal fat increased in study of Deaton et al. (1981) $-1.72,1.93$ and $2.05 \%$, respectively (males); $1.97,2.19$ and $2.41 \%$, respectively (females) in chickens reared at $21{ }^{\circ} \mathrm{C}$ and $1.61,1.88$ and $2.14 \%$, respectively (females) and $1.97,2.20$ and $2.36 \%$, respectively at rearing temperature $29^{\circ} \mathrm{C}$. They found higher amount of abdominal fat in females than in males broiler chickens what is in a conflict with our results and also point the importance of rearing temperature. Even higher amount of abdominal fat was described by Hidayat et al. (2016) after application of probiotic Bacillus spp into feed mixture of broiler chickens $50 \mathrm{mg} \cdot \mathrm{kg}^{-1} \mathrm{FM}(3,18 \%)$ and $60 \mathrm{mg} \cdot \mathrm{kg}^{-1} \mathrm{FM}$ $(3.15 \%)$ compared to control group $(3.79 \%)$

The experiment of Haščík et al. (2018) was aimed at addition of bee pollen extract (400 mg. $\mathrm{kg}^{-1} \mathrm{FM}$ ), propolis extract (400 mg. $\mathrm{kg}^{-1} \mathrm{FM}$ ), probiotics (3.3\% to drinking water) and their combinations. The results of the experiment confirmed the lowest proportion of abdominal, gizzard, heart and total fats, respectively, from carcass weight in the experimental groups fed with additional propolis extract to FM $(1.30 \%, 0.44 \%, 0.05 \%$ and $2.06 \%$, respectively), what is quite well-comparable also with our results. Results of Haščík et al. (2015) showed that weight of total internal fat of chickens fed with the additional linoleic acid was higher (males $2.51 \%$ and females $-2.75 \%$ ) compared to control group without addition (males 2.38 and females $-2.61 \%$ ). Similar results as ours were found by Haščík et al (2019), when total internal fats were in the control group $1.94 \%$, in the experimental group supplemented with bee pollen extract + probiotics $2.01 \%$ and in the experimental group supplemented with propolis extract + probiotics $1.94 \%$.

\section{CONCLUSION}

The aim of this work was to investigate the effect of grape, flax and pumpkin pomace as voluminous agricultural by-products on the percentage of internal fats from the carcass weight of Ross 30 broiler chickens. As the solved internal fats are considered as waste in poultry processing, the application of RGP, which generally 
increased their amount in both females and males in experimental groups E2 and E3, seems inappropriate. On the other hand, the addition of flax (except of E5 group in females) and pumpkin pomace either did not increase or even decrease the percentage of internal fats, even significantly in comparison with either the control group or the mentioned experimental groups E2 and E3. The most significant reduction in the total fat content was observed especially in males after the application of pumpkin pomace $(\mathrm{P} \leq 0.001)$ in comparison almost with all other groups. Overall, however, it should be noted that there are too few of the same studies that could confirm or refute our findings. It would also be useful to look for ways to reintroduce chicken fat into the food chain, given its favorable fatty acid composition. On the other hand, the results also show that the experimental groups fed with RGP also had a higher carcass weight as important economical parameter, especially in males compared to the groups fed with pumpkin and flax pomace.

Acknowledgments: This publication was supported by the Operational program Integrated Infrastructure within the project: Demand-driven research for the sustainable and inovative food, Drive4SIFood 313011V336, cofinanced by the Euruopean Regional Development Fund, [VEGA] under grant [no. 1/0722/19] and [KEGA] [no. 027SPU-4/2019].

\section{REFERENCES}

Abid, M. \& Touzani, M. (2017). First step of waste chicken skin valorization by production of biodiesel in Morocco. Journal of Materials and Environmenta Science, 8, 2372-2380.

Aditya, S., Ohh, S.-J., Ahammed, M., \& Lohakare, J. (2018). Supplementation of grape pomace (Vitis vinifera) in broiler diets and its effect on growth performance, apparent total tract digestibility of nutrients, blood profile, and meat quality. Animal Nutrition, 4(2), 210-214. https://doi.org/10.1016/i.aninu.2018.01.004

Barbut, S. (2015). Chapter 18: Waste treatment and by-products. In The Science of Poultry and Meat Processing. Guelph: University of Guelph. 1-27.

Beres, C., Costa, G. N. S., Cabezudo, I., da Silva-James, N. K., Teles, A. S. C., Cruz, A. P. G., ... Freitas, S. P. (2017). Towards integral utilization of grape pomace from winemaking process: A review. Waste Management, 68, 581-594. https://doi.org/10.1016/j.wasman.2017.07.017

Brenes, A., Viveros, A., Goñi, I., Centeno, C., Sáyago-Ayerdy, S. G., Arija, I., \& Saura-Calixto, F. (2008). Effect of Grape Pomace Concentrate and Vitamin E on Digestibility of Polyphenols and Antioxidant Activity in Chickens. Poultry Science, 87(2), 307-316. https://doi.org/10.3382/ps.2007-00297

Bulletin of MARD SR (Ministry of Agriculture and Rural Development of the Slovak Republic). 2005. Decree of Ministry of Agriculture and Rural Development of the Slovak Republic no. 2080/2005-100 of 23 March 2005 changing and amending Decree of Ministry of Agriculture and Rural Development of the Slovak Republic no. 1497/1/1997-100 of 7 October 1997 regulating feed materials for the manufacture of feed mixtures and farm feeds.

Costa, M. C., Bessegatto, J. A., Alfieri, A. A., Weese, J. S., Filho, J. A. B., \& Oba A. (2017). Different antibiotic growth promoters induce specific changes in the cecal microbiota membership of broiler chicken. Plos One, 12(2), e0171642. https://doi.org/10.1371/journal.pone.0171642

Čech, M., Haščík, P., Pavelková, A., Čuboň, J., Bučko, O., Tkáčová, J., Kačániová, M., Bobko, M., Imrich, I. \& Šár, K. (2021). Chemical composition of muscle after red grape pomace application in the nutrition of broiler chickens. Journal of Microbiology, Biotechnology and Food Sciences, 10(6). https://doi.org/10.15414/jmbfs.3726

Deaton, J. W., Mcnaughton, J. L., Reece, F. N., \& Lott, B. D. (1981). Abdominal Fat of Broilers as Influenced by Dietary Level of Animal Fat. Poultry Science, 60(6), 1250-1253. https://doi.org/10.3382/ps.0601250

Del Pino-García, R., González-SanJosé, M. L., Rivero-Pérez, M. D., GarcíaLomillo, J., \& Muñiz, P. (2017). The effects of heat treatment on the phenolic composition and antioxidant capacity of red wine pomace seasonings. Food Chemistry, 221, 1723-1732. https://doi.org/10.1016/j.foodchem.2016.10.113

Donohue, M., \& Cunningham, D. L. (2009). Effects of grain and oilseed prices on the costs of US poultry production. Journal of Applied Poultry Research, 18(2), 325-337. https://doi.org/10.3382/japr.2008-00134

El Boushy, A. R. Y., \& van der Poel, A. F. B. (1994). Poultry Feed from Waste. Boston: Springer, MA, USA. https://doi.org/10.1007/978-1-4615-2654-4

Erener, G., Ocak, N., Garipoğlu, A. V., \& Şahin, A. (2016). Insoluble granite-grit allows broiler chicks to have better growth performance and gut health. Revisto Brasileira de Zootecnia, 45(11), 650-654. https://doi.org/10.1590/s180692902016001100002

FAO. 2021. Food Outlook: Biannual Report on Global Food Markets. Rome https://doi.org/10.4060/cb4479en

Fontana, A. R., Antoniolli, A., \& Bottini, R. (2013). Grape Pomace as a Sustainable Source of Bioactive Compounds: Extraction, Characterization, and Biotechnological Applications of Phenolics. Journal of Agricultural and Food Chemistry, 61(38), 8987-9003. https://doi.org/10.1021/jf402586f

García-Lomillo, J., \& González-SanJosé, M. L. (2016). Applications of Wine Pomace in the Food Industry: Approaches and Functions. Comprehensive Reviews in Food Science and Food Safety, 16(1), 3-22. https://doi.org/10.1111/1541$\underline{4337.12238}$
Gioielli, L. A., Ming, C. C., \& Sotero Solis, V. (2002). Abdominal chicken fat fractionation. Grasas $\quad y \quad$ Aceites, 53(3). https://doi.org/10.3989/gya.2002.v53.i3.320

Griffiths, L., Leeson, S., \& Summers, J. D. (1978). Studies on Abdominal Fat with Four Commercial Strains of Male Broiler Chicken. Poultry Science, 57(5), 11981203. https://doi.org/10.3382/ps.0571198

Haščík, P., Čech, M., Čuboň, J., Bobko, M., Arpášová, H., Pavelková, A., Kačániová, M., Tkáčová, J. \& Čeryová, N. (2020). Effect of grape pomace supplementation on meat performance of broiler chicken ross 308. Journal of Microbiology, Biotechnology and Food Sciences, 10(1), 140-144. https://doi.org/10.15414/jmbfs.2020.10.1.140-144

Haščík, P., Cuboň, J., Bebejová, A., Šmýkalová, H., \& Kačániová, M. (2015). Chicken carcass structure fed with addition of linoleic acid. Journal of Microbiology, Biotechnology and Food Sciences, 4(Special issue 3), 59-62. https://doi.org/10.15414/jmbfs.2015.4.special3.59-62

Haščík, P., Kačániová, M. \& Vavrišinová, K. (2014). Vplyv probiotických preparátov na jatočné ukazovtele a senzorickú kvalitu mäsa výkrmových kurčiat Influence of probiotic preparations on carcass parameters and sensory quality of chicken meat. Nitra: SUA in Nitra. 162 p.

Haščík, P., Pavelková, A., Arpášová, H., Čuboň, J., Kačániová, M. \& Kunová, S. (2019). The effect of bee products and probiotic on meat performance of broiler chickens. Journal of Microbiology, Biotechnology and Food Sciences, 9(1), 8892. https://doi.org/10.15414/jmbfs.2019.9.1.88-92

Haščík, P., Trembecká, L., Bobko, M., Čuboň, J., Tóth, T., \& Ducková, V. (2018). Effect of natural feed supplements on meat performance and meat quality of broiler chickens. Český Těšín: 2 THETA. $146 \mathrm{p}$

Haščík, P., Trenbecká, L., Bobko, M., Kačániová, M., Čuboň, J., Kunová, S., \& Bučko, O. (2016). Effect of diet supplemented with propolis extract and probiotic additives on performance, carcass characteristics and meat composition of broiler chickens. Potravinarstvo, 10(1). https://doi.org/10.5219/581

Heuze, V. \& Tran, G. (2020). Grape Pomace. Feedipedia, a programme by INRAE, CIRAD, AFZ and FAO. https://www.feedipedia.org/node/691

Chen, L. R., Suyemoto, M. M., Sarsour, A. H., Cordova, H. A., Oviedo-Rondón, E. O., Wineland, M., Barnes, H.J. \& Borst, L. B. (2019). Temporal characterization of wooden breast myopathy ("woody breast") severity and correlation with growth rate and lymphocytic phlebitis in three commercial broiler strains and a randombred broiler strain. Avian Pathology, 48(4), 319-328. https://doi.org/10.1080/03079457.2019.1598541

Ilyas, T., Chowdhary, P., Chaurasia, D., Gnansounou, E., Pandey, A., \& Chaturvedi, P. (2021). Sustainable green processing of grape pomace for the production of value-added products: An overview. Environmental Technology \& Innovation, 23, 101592. https://doi.org/10.1016/j.eti.2021.101592

International Organisation of Vine and Wine. https://www.oiv.int/en/statistiques/ (Accesed 17/09/2021)

Jurčaga, L., Bobko, M., Haščík, P., Bobková, A., Demianová, B., Belej, L. \& Kročko, M. (2021). Effect of dietary red grape pomace on lipid oxidation in meat of broiler chickens. Journal of Microbiology, Biotechnology and Food Sciences, 10(5). https://doi.org/10.15414/jmbfs.3769

Kiraz, S., \& Şengül, T. (2011). Relationship between abdominal fat and methionine deficiency in broilers. Czech Journal of Animal Science, 50(No. 8), 362-368. https://doi.org/10.17221/4178-cjas

MacDonald, J. M. 2014. Technology, organization, and financial performance in US broiler production. United States Department of Agriculture, Economic Research Service. $\quad$ EIB https://www.ers.usda.gov/webdocs/publications/43869/48159_eib126.pdf?v=234 3.6.

Maier, T., Göppert, A., Kammerer, D. R., Schieber, A., \& Carle, R. (2007) Optimization of a process for enzyme-assisted pigment extraction from grape (Vitis vinifera L.) pomace. European Food Research and Technology, 227(1), 267-275. https://doi.org/10.1007/s00217-007-0720-y

Martínez, Y., Valdivié, M., Martínez, O., Estarrón, M. \& Córdova, J. (2010). Utilization of pumpkin (Cucurbita moschata) seed in broiler chicken diets. Cuban Journal of Agricultural Science, 44(4):387-392.

Mendes, A., Rettore, D., Ramos, A., da Cunha, S., de Oliveira, L. \& Ramos, E. (2014). Milano type salami elaborated with fibers of red wine byproducts. Ciencia Rural, 44:1291

Moser, B. R. (2010). Biodiesel Production, Properties, and Feedstocks. Biofuels, 285-347. https://doi.org/10.1007/978-1-4419-7145-6 15

Hidayat, M.N., Malaka, R., Agustina, L. \& Pakiding, W. 2016. Abdominal Fat Percentage and Carcass Quality of Broiler Given Probiotics Bacillus spp. Scientific Research Journal (SCIRJ), 4(10), 33-37.

National Chicken Council.

https:/www nationalchickencouncilorg/questions-andable at: production-

2/\#: :text=As $\% 20$ of $\% 20$ April $\% 202019 \% 2 \mathrm{C} \% 20$ more $\% 20$ than $\% 2050 \% 25 \% 20$ of ,those $\% 20$ questions $\% 20$ and $\% 20$ address $\% 20$ some $\% 20$ of $\% 20$ those $\% 20$ concerns. Newkirk, R., (2015). Flax Feed Industry Guide. Winnipeg: Canadian International Grains Institute, Manitoba. https://flaxcouncil.ca/wpcontent/uploads/2015/02/Flax-Feed-Industry-Guide-Final.pdf 
Newman, L. (2018). New strategies in coccidiosis control to meet customer demands. International Poultry Production, 26 (3), 15-17. https://www.scribd.com/document/488839258/pp26-3p15

Nunes, J. O., Bertechini, A. G., Brito, J. Á. G. de, Makiyama, L., Mesquita, F. R., \& Nishio, C. M. (2012). Evaluation of cysteamine associated with different energy patterns in diets for broiler chickens. Revista Brasileira de Zootecnia, 41(8), 19561960. https://doi.org/10.1590/s1516-35982012000800022

O’Neill, H. V. M., Mathis, G., Lumpkins, B. S., \& Bedford, M. R. (2012). The effect of reduced calorie diets, with and without fat, and the use of xylanase on performance characteristics of broilers between 0 and 42 days. Poultry Science, 91(6), 1356-1360. https://doi.org/10.3382/ps.2011-01867

Petracci, M., Soglia, F., Madruga, M., Carvalho, L., Ida, E., \& Estévez, M. (2019).

Wooden-Breast, White Striping, and Spaghetti Meat: Causes, Consequences and Consumer Perception of Emerging Broiler Meat Abnormalities. Comprehensive Reviews in Food Science and Food Safety, 18(2), 565-583. https://doi.org/10.1111/1541-4337.12431

Ritter, G. D., Acuff, G. R., Bergeron, G., Bourassa, M. W., Chapman, B. J. Dickson, J. S, Opengart, K., Salois, M.J., Singer, R.S. \& Storrs, C. (2019) Antimicrobial-resistant bacterial infections from foods of animal origin: understanding and effectively communicating to consumers. Annals of the New York Academy of Sciences, 1441(1), 40-49. https://doi.org/10.1111/nyas.14091

Salois, M. (2017). The cost of broiler welfare standards. Chicken Marketing Summit. Elanco: 2017. https://www.wattglobalmedia.com/wpcontent/uploads/2017/07/6-Salois-Elanco-2017-CMS-presentation.pdf

Taufik, M., \& Maruddin, F. (2019). The effect of garlic solution supplementation on performance, carcass weight and abdominal fat of broiler chickens. IOP Conference Series: Earth and Environmental Science, 247, 012039. https://doi.org/10.1088/1755-1315/247/1/012039

Tůmová, E. \& Teimouri, A. (2010). Fat deposition in the broiler chicken: a review. Scientia Agriculturae Bohemica, 41(2), 121-128

Turcu, R.P., Olteanu, M., Criste, R.D., Panaite, D.T., Ropota, M., Vlaicu, P.A. \& Soica, C. (2018). Use of flaxseed meal and grape seed meal (2\% and $3 \%)$ as natural antioxidant in broiler diets. Universitatea de Științe Agricole și Medicina Veterinara "Ion Ionescu de la Brad" Iași, 69, 200-206.

Vikman, M., Siipola, V., Kanerva, H., Slizyte, R. \& Wikberg, H. (2017). Poultry by-products as potential source of nutrients. Advances in Recycling and Waste Management, 2, 1-5.

Wafar, R., Hannison, M., Abdullahi, U., \& Makinta, A. (2017). Effect of Pumpkin (Cucurbita pepo L.) Seed Meal on the Performance and Carcass Characteristics of Broiler Chickens. Asian Journal of Advances in Agricultural Research, 2(3), 1-7. https://doi.org/10.9734/ajaar/2017/35742 